\title{
Calcium in the North Pacific water and the effect of organic matter on the calcium-alkalinity relation
}

\author{
Shizuo Tsunogai and Yasunori Watanabe \\ Department of Chemistry, Graduate School of Fisheries, Hokkaido Universiy, \\ Hakodate 041, Japan
}

(Received January 8, 1981: Accepted April 24, 1981)

\begin{abstract}
The concentrations of $\mathrm{Ca}$ in the surface and deep waters of the North Pacific and the Bering Sea have been determined with a highly precise method. The deep water contains Ca relative to chlorinity by $0.8 \%$ more than the warm surface water of the western North Pacific, whereas it contains Ca by only $0.4 \%$ more than does the cold surface water of the northern North Pacific. Based on the results the amount of $\mathrm{Ca}$ dissolved in the deep water column of $4 \mathrm{~km}$ long is calculated to be $9 \mathrm{gCa} / \mathrm{m}^{2} / \mathrm{yr}$. In the surface water of the productive Bering Sea, alkalinity is found to be controlled chiefly by the formation and decomposition of organic matter rather than the formation and dissolution of $\mathrm{CaCO}_{3}$. Furthermore a plot of Ca versus potential alkalinity defined by BREWER et al. (1976) gives virtually a slope of 0.5 for upper waters above $1.5 \mathrm{~km}$ depth. It, however, is difficult to demonstrate the relation between $\mathrm{Ca}$ and alkalinity for the deep water collected from the northern North Pacific alone.
\end{abstract}

\section{INTRODUCTION}

Among major constituents in sea water $\mathrm{Ca}$ is an only element which varies with depth in its ratio to chlorinity (e.g. CulKIN and Cox, 1966; Tsunogai et al., 1973a; HoRIBE et al., 1974). This tendency of the vertical variation that deep waters have a higher $\mathrm{Ca}$ to chlorinity ratio than the surface water above them agrees qualitatively in all the values reported after DITTMar (1884). However, the degree of the variation differs from report to report. This variation may be due to the difficulty in the analytical methods requiring an error less than $0.1 \%$ and the alteration of sea water during storage after sampling, although the variation is sometimes real owing to the geographically variable ratios of $\mathrm{Ca}$ to chlorinity. We have intended to apply a more precise analytical method for $\mathrm{Ca}$ to the deep water of the northern North Pacific which is expected to be the oldest among the deep waters (TsuNOGAI, 1980).

The difference in the $\mathrm{Ca}$ to chlorinity ratio between the deep and surface waters is considered to be caused by the formation and dis- solution of $\mathrm{CaCO}_{3}$ as follows,

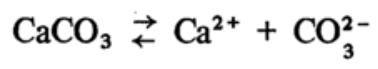

In the surface water $\mathrm{CaCO}_{3}$ is formed by the biological activity and the precipitate of $\mathrm{CaCO}_{3}$ is dissolved in the deep water owing to the increased solubility of $\mathrm{CaCO}_{3}$ at lower temperatures and higher pressures. The dissolution of one mole of $\mathrm{CaCO}_{3}$ produces one mole of $\mathrm{Ca}$ ions and one mole of carbonate ions which are subsequently distributed to various carbonate species reacting with hydrogen ions, and thus two equivalents of alkalinity is produced in sea water. In the actual ocean, however, TsunOGAI et al. (1973a) and HoRIBE et al. (1974) have found that the ratio of increased $\mathrm{Ca}$ to increased alkalinity relative to the surface water above the deep water is somewhat greater than the theoretical value of 0.5 for the Pacific deep water. For this discrepancy BREWER et al. (1975) have suggested that the alkalinity has been titrated with protons derived from the oxidative decomposition of organic matter in the deep water. They have defined the potential 
alkalinity as follows,

$$
\Delta \mathrm{PA}=\Delta \mathrm{TA}+\Delta \mathrm{NO}_{3}+\Delta \mathrm{PO}_{4}
$$

where $\triangle \mathrm{PA}$ and $\triangle \mathrm{TA}$ are the potential alkalinity and total alkalinity differences, in $\mu \mathrm{eq} / \mathrm{kg}$, between two water masses, and $\triangle \mathrm{NO}_{3}$ and $\Delta \mathrm{PO}_{4}$ are the differences in concentrations of nitrate and phosphate, in $\mu \mathrm{M} / \mathrm{kg}$, between the same two water masses. This concept is derived from the following stoichiometrical relation for the formation and decomposition of organic matter proposed by REDFIELD et al. (1963);

$$
\begin{aligned}
& \left(\mathrm{CH}_{2} \mathrm{O}\right)_{106}\left(\mathrm{NH}_{3}\right)_{16} \mathrm{H}_{3} \mathrm{PO}_{4}+138 \mathrm{O}_{2} \\
& \quad \rightleftarrows 106 \mathrm{CO}_{2}+16 \mathrm{HNO}_{3}+\mathrm{H}_{3} \mathrm{PO}_{4}+122 \mathrm{H}_{2} \mathrm{O}
\end{aligned}
$$

This reaction involves that the consumption of 276 atoms of dissolved oxygen produces 17 protons if the phosphoric acid supplies one proton. CHEN (1978) and SHILLER and GIESKES
(1980) have also discussed the effect of decomposition of organic matter on the alkalinity change. The relation between the consumed oxygen and regenerated nutrients has proved to be true in the ocean water (REDFIELD et al., 1963; TsunogaI, 1972a). Using the data obtained by HORIBE et al. (1974), BREWER et al., (1975) have found that a plot of Ca versus potential alkalinity gives a slope of 0.5 within the limit of uncertainties. In their regression line, however, the data for the surface water of different origins are included and thus we do not know whether or not both the deep and surface waters have the same preformed values of $\mathrm{Ca}$, which are defined for the identification of water masses by REDFIELD et al. (1963). ShILlER and GiesKes (1980) have also pointed out this, but the preformed $\mathrm{Ca}$ is difficult to be estimated. When we make a plot of $\mathrm{Ca}$ against total alkalinity or potential alkalinity using only the data for the deep waters below $1 \mathrm{~km}$ depth in the South Pacific obtained by

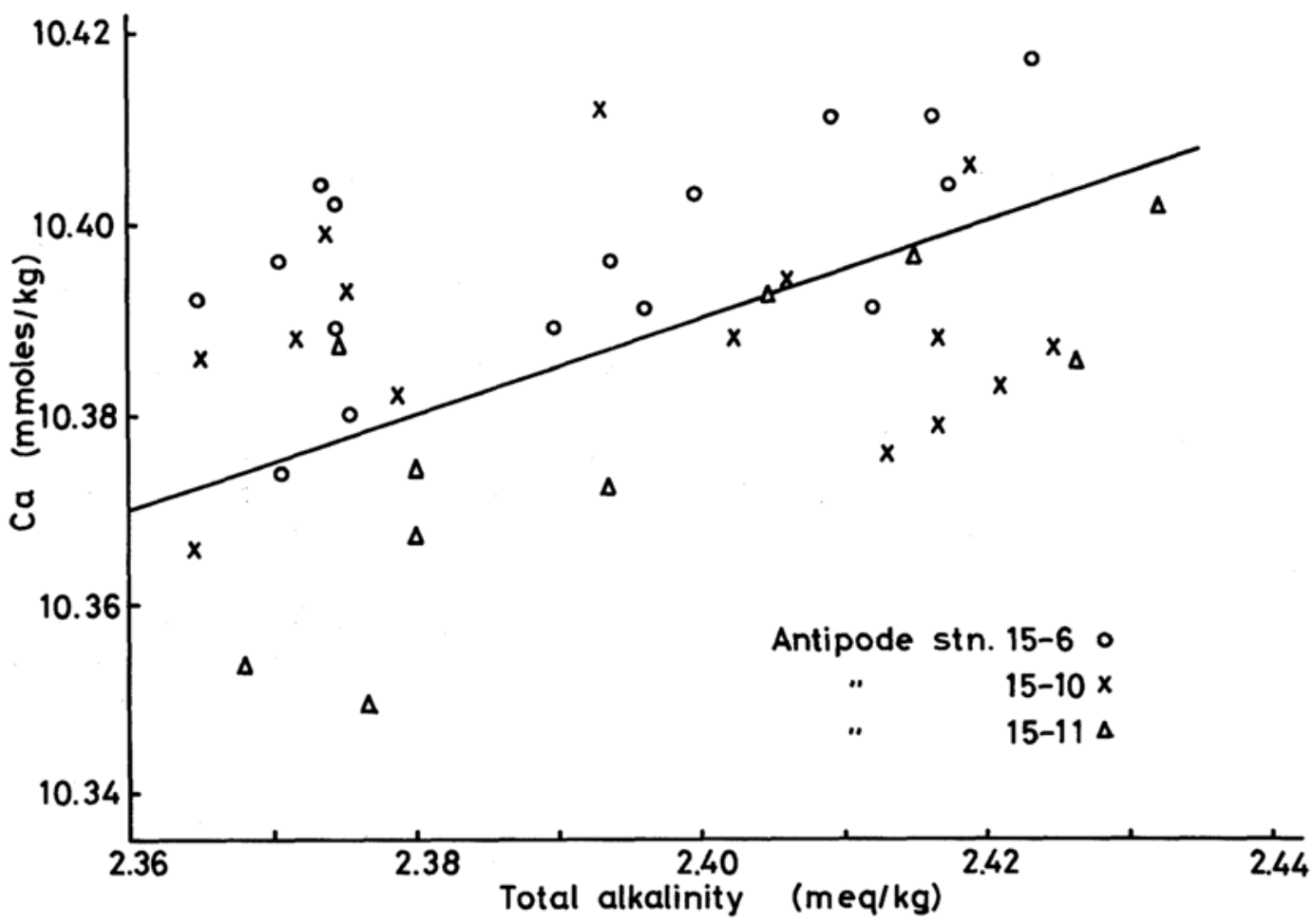

Fig. 1a 


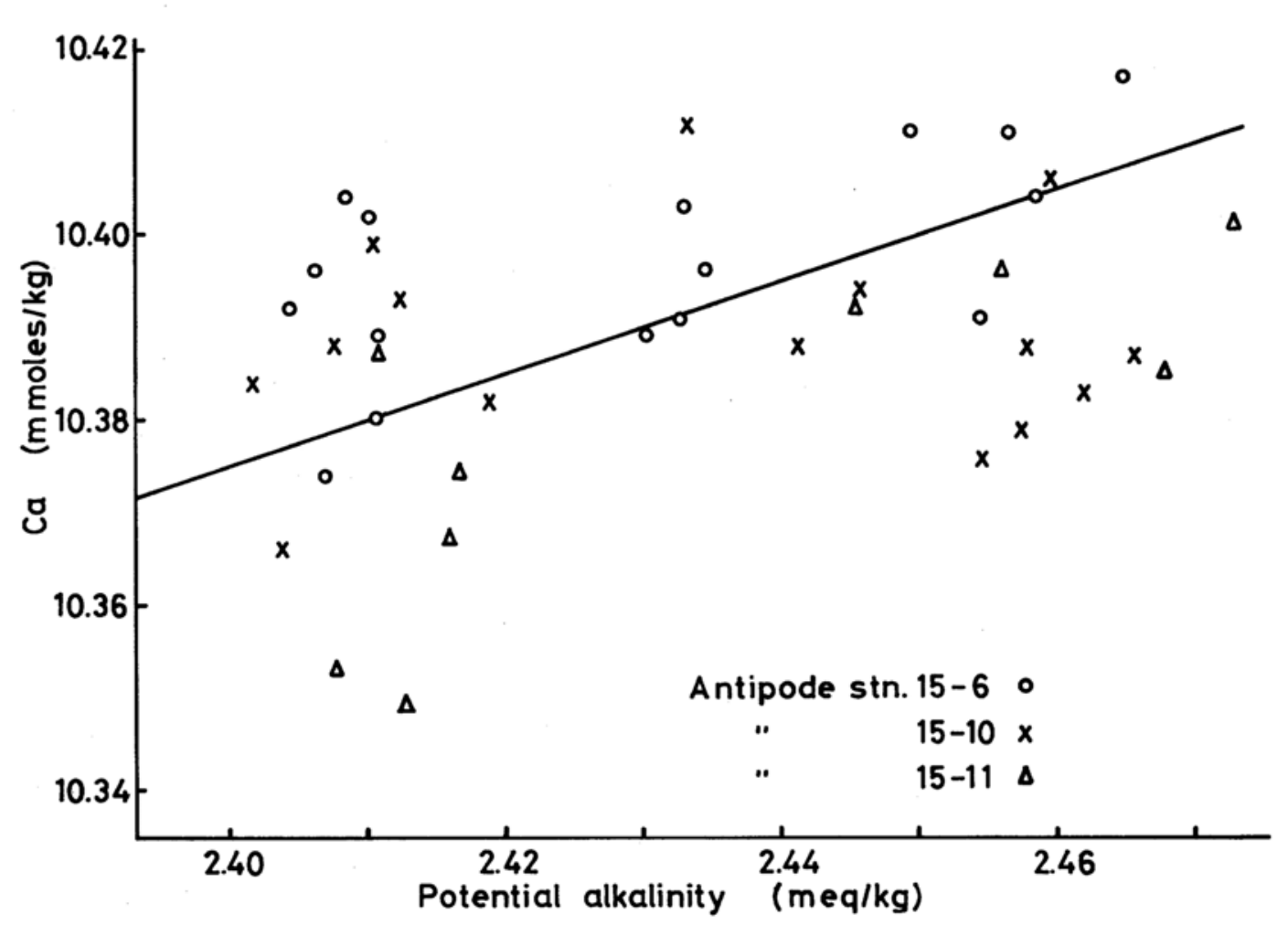

Fig. 1b

Fig. 1. The relations between $\mathrm{Ca}$ and total alkalinity (Fig. 1a), and Ca and potential alkalinity (Fig. $1 \mathrm{~b}$ ), for waters below $1 \mathrm{~km}$ depth. These data are cited from HoRIBE et al. (1975) and normalized to a salinity of $35.000 \%$. The slope of straight line in the figures shows a theoretical value of 0.5 .

HORIBE et al. (1974) as shown in Fig. 1, the plot is so scattered that we cannot neglect the possibility that $\mathrm{Ca}$ versus total alkalinity (Fig. 1a) produces a slope of 0.5 , as compared with the relation between $\mathrm{Ca}$ and potential alkalinity (Fig. 1b). Furthermore the stoichiometrical relationship of REDFIED et al. (1963) is true for nutrients in the biological processes, but we have not yet proved the relationships for other constituents such as metal components including alkalinity, although there is a culture experiment on the alkalinity change during phytoplankton growth (BREwER and Goldman, 1976). Therefore we should examine the relation between $\mathrm{Ca}$ and alkalinity for samples collected from the same water mass using a precise analytical method. In a highly productive sea such as the Bering Sea, the relation is expected to be observed more clearly, if it exists.

\section{Samples and ANalytical Methods}

Sea water samples were collected in the western and northern North Pacific and the Bering Sea during cruises, $\mathrm{KH}-75-4, \mathrm{KH}-77-2$, $\mathrm{KH}-77-4, \mathrm{KH}-78-1$ and $\mathrm{KH}-78-3$ of R.V. Hakuho-Maru of University of Tokyo. The sampling stations are shown in Fig. 2. The samples were stored in polyethylene bottles, and their salinities were determined just before the titration of $\mathrm{Ca}$ in the laboratory on land.

The analytical method of TsunOGaI et al., (1968) was used for the determination of $\mathrm{Ca}$ in sea water with some minor modifications as schematically shown in Fig. 3. The most important improvement is based on the fact that the titers of EGTA solution increases with the amount of EGTA solution added prior to the development of color with an indicator, GHA 
(Fig. 4). The addition of EGTA solution in advance is essential for the precise determination of $\mathrm{Ca}$. The increase in the titer may be due to an unstable nature of GHA in water, because a part of GHA is decomposed in water before being extracted to the organic phase to be titrated. We, therefore, roughly calculated

the end point for each sample from its salinity and the titer of a substandard sea water before the titration, assuming that the volume of titer was proportional to salinity, and we added the EGTA solution in advance by $0.20 \mathrm{ml}$ less than the titer calculated as $\alpha$ in Fig. 3. After finishing the first titration, we repeated the titration

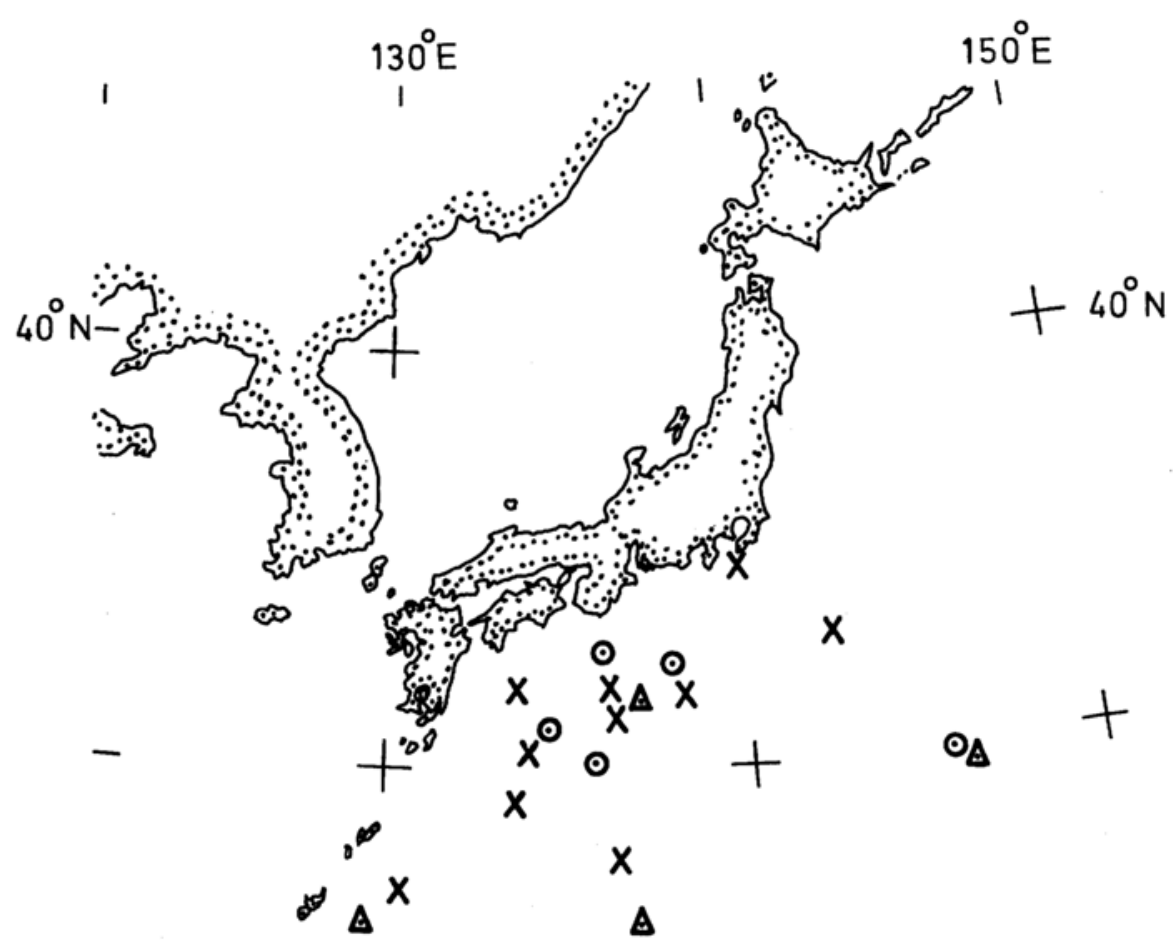

$\Delta$

$20^{\circ} \mathrm{N}-$

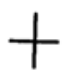

$\Delta$

$\Delta$

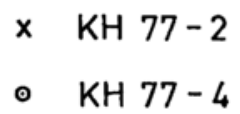

$\Delta \quad \mathrm{KH} 78-1$

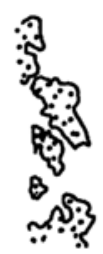

$\Delta$
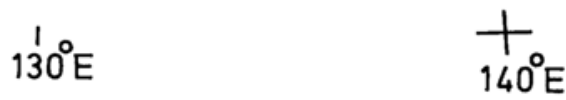

Fig. 2a 


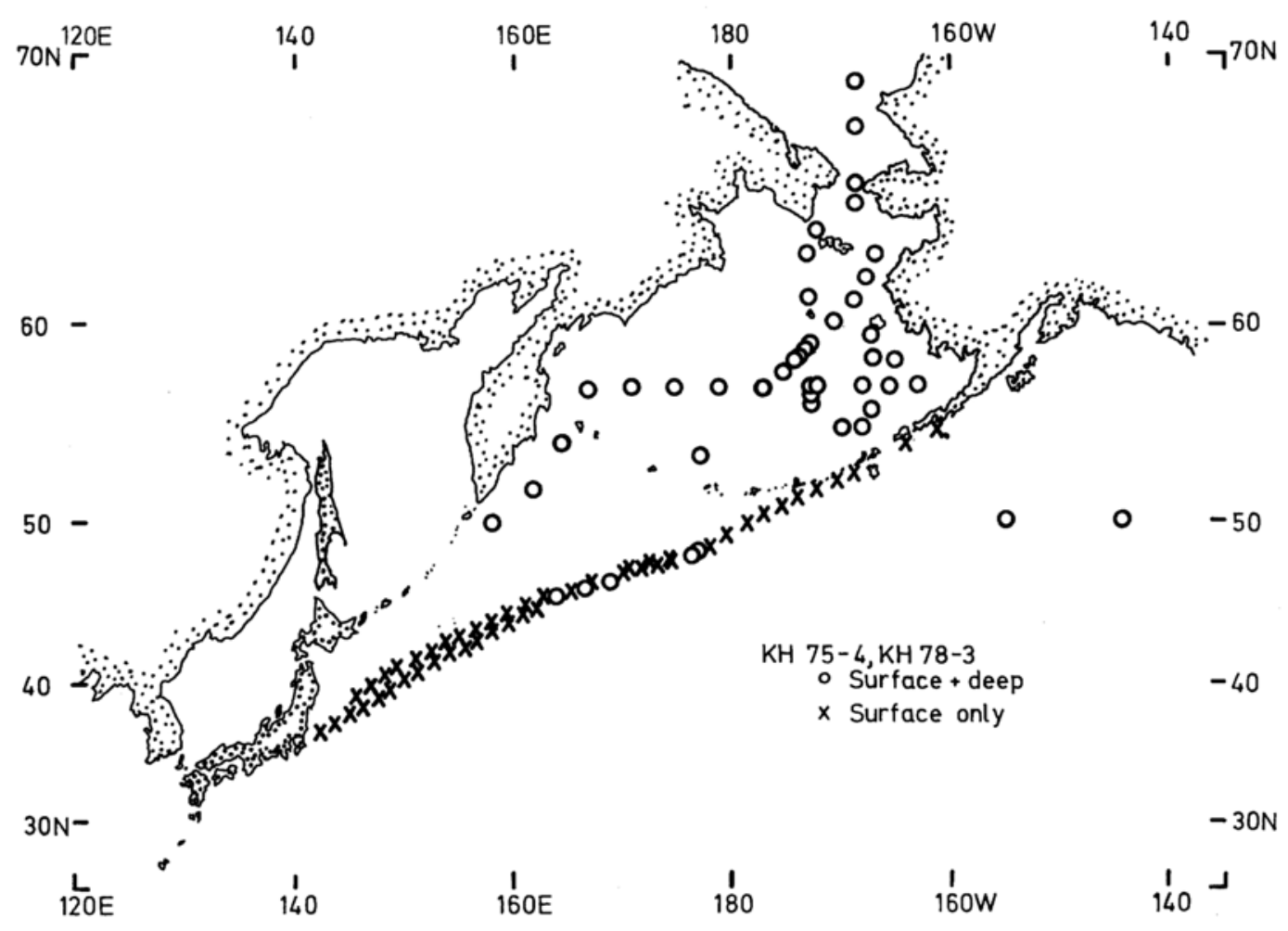

Fig. 2b

Fig. 2. Sampling stations in the western North Pacific (Fig. 2a) and in the northern North Pacific and the Bering Sea (Fig. 2b).

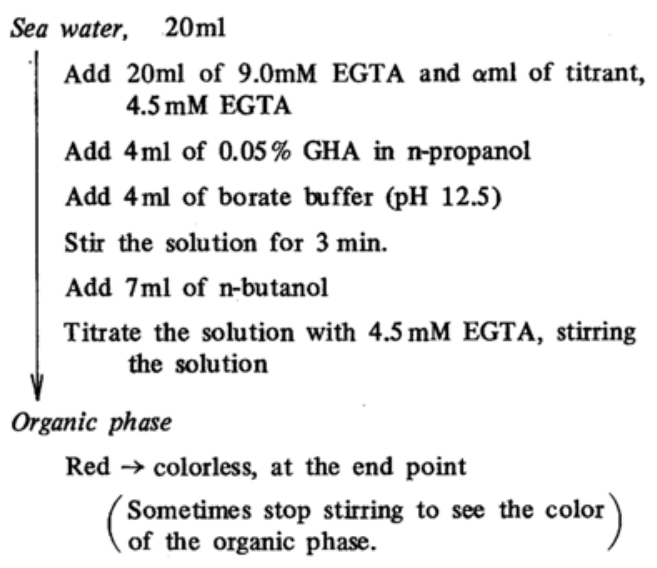

Fig. 3. Determination of $\mathrm{Ca}$.

procedure for $\mathrm{Ca}$ using the amount subtracted by $0.20 \mathrm{ml}$ from the titer previously obtained as $\alpha$ in Fig. 3, until the end point of the last two titrations coincided with each other within a permissible limit of $0.03 \mathrm{ml}$. The standard deviation obtained from 301 replicate titrations for the same sea water was $0.016 \mathrm{ml}$ which corresponded to the relative error of $0.036 \%$. Thus the analytical error in the above determination (99\% confidence level) is certainly less than $0.1 \%$. Of course it is necessary to re-determine salinity prior to the titration. The increase in salinity during storage is apt to decrease the $\mathrm{Ca}$ to salinity ratio. We have found a fact that the salinity increase of $1 \%$ decreases the $\mathrm{Ca}$ to salinity ratio by $0.3 \%$, at most, which is estimated from the depression in the vertical profiles of the ratios, although we do not exactly know the cause of this fact. The data obtained for waters which changed their salinities more than $0.3 \%$ during the storage have been deleted from the results in this study.

For accuracy, we have assumed the $\mathrm{CaCO}_{3}$ content of $99.803 \%$ for our standard $\mathrm{CaCO}_{3}$ 
reagent which has been determined in the previous paper (TSUNOGAI et al., 1973a) and the Sr to chlorinity ratio of 0.41 for all the sea water. The data obtained in this study appear to be smaller by about $0.4 \%$ than those obtained previously by TsUNOGAIet al. (1973a), although the same $\mathrm{CaCO}_{3}$ standard was used. The difference may be caused by the incomplete titration for less stable $\mathrm{Sr}$ only at the standardization of EGTA solution or unexpected contaminations of metals reactive on EGTA in the standard synthetic sea water in the previous work.

We have also determined alkalinity of sea water on board the vessel during the cruises $\mathrm{KH}$ 75-4 and KH-78-3, using the methods of TsunogaI et al. (1978). The precision of the method is estimated to be more than $99.7 \%$ (or error less than $0.3 \%$ ) from the duplicate analysis of the same sample, because a mean of the differences in the duplicate determinations was $2.8 \mu \mathrm{eq} / 1$ for 293 samples.

\section{RESUlTS AND DiscusSion}

1) Distribution of $\mathrm{Ca}$ and its dissolution rate in the deep water

The more precise data obtained here confirm the conclusion for the distribution of $\mathrm{Ca}$ in the Pacific previously given by Tsunogal et al. (1973a). The vertical distributions of $\mathrm{Ca}$ in the North Pacific are shown in Fig. 5 as examples and the measured $\mathrm{Ca}$ concentrations are summarized in Table 1. Since a nonconservative portion of $\mathrm{Ca}$ is extremely smaller than the conservative one in sea water, the $\mathrm{Ca}$ contents are normalized to salinity of $35.000 \%$.

The lowest value of the normalized concentration of $\mathrm{Ca}$ was $10.13 \mathrm{mM}$ in the warm surface water of the Kuroshio region and the

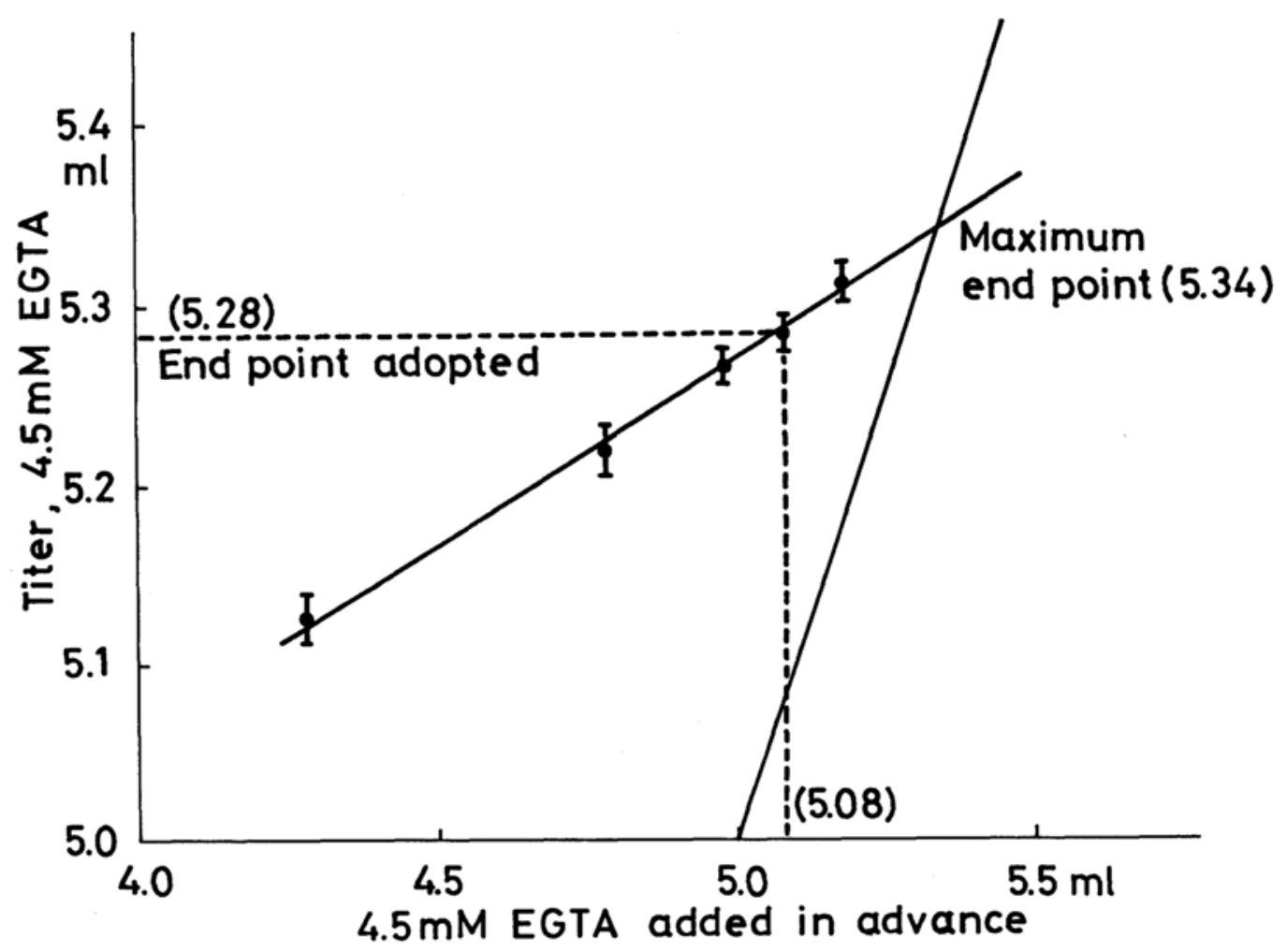

Fig. 4. Apparent end points obtained by adding various amounts of $4.5 \mathrm{mM}$ EGTA and $20 \mathrm{ml}$ of $9.0 \mathrm{mM}$ EGTA in advance. The end point adopted is of the case that $4.5 \mathrm{mM}$ EGTA is added in advance by $0.20 \mathrm{ml}$ less than the titer. 
highest one was $10.26 \mathrm{mM}$ in the deep water. Thus the variation of $\mathrm{Ca} / \mathrm{Cl}$ ratio is $1.3 \%$ at most in the pelagic ocean excluding marginal seas, because the greatest variation is expected to be found in the region studied here where the oldest water has been found (TsuNOGAI, 1980).

The horizontal variation of the $\mathrm{Ca}$ content is not significant for waters below $1 \mathrm{~km}$ depth (Table 1), but the warm surface water contains less $\mathrm{Ca}$ relative to salinity or chlorinity than does the cold surface water. The Ca content increases with depth down to 2 or $3 \mathrm{~km}$ depth, although the tendency of increase with depth is much smaller in the region of cold surface water. There must be a source of $\mathrm{Ca}$ in the deep water even in the water of 2 to $3 \mathrm{~km}$ depth which is usually above the compensation depth of $\mathrm{CaCO}_{3}$ in the pelagic sediments, because a weak maximum in the vertical profile of $\mathrm{Ca}$ appears to exist in the water like dissolved salica.

The amount of $\mathrm{Ca}$ dissolved in the water column can be calculated by applying a onedimensional diffusion and advection model (Craig, 1969; TsunogaI, 1972a), if the horizontal flux, the product of the horizontal diffusion constant and the concentration gradient, is much smaller than the vertical flux. We have devised a simple calculation method for the model and obtained the dissolution rate of $\mathrm{Ca}$ ( $\mathrm{J}$ in $\mathrm{m} \mathrm{mole} / \mathrm{cm}^{3} / \mathrm{yr}$ ) by intergrating graphycally as shown in Fig. 6. The following solutions for a conservative (S) and a non-conservative (R)

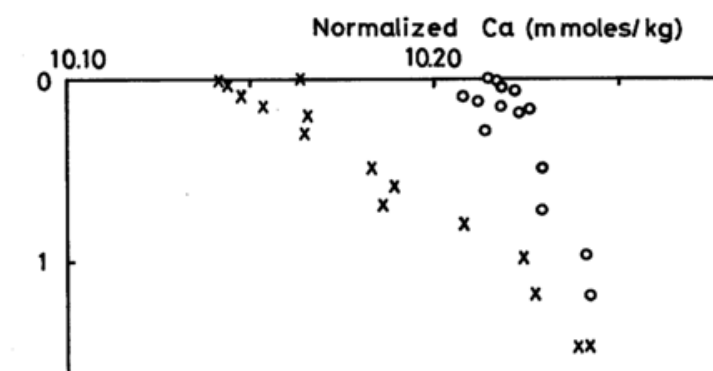

$\times$ KH 78-1 Stn. 2

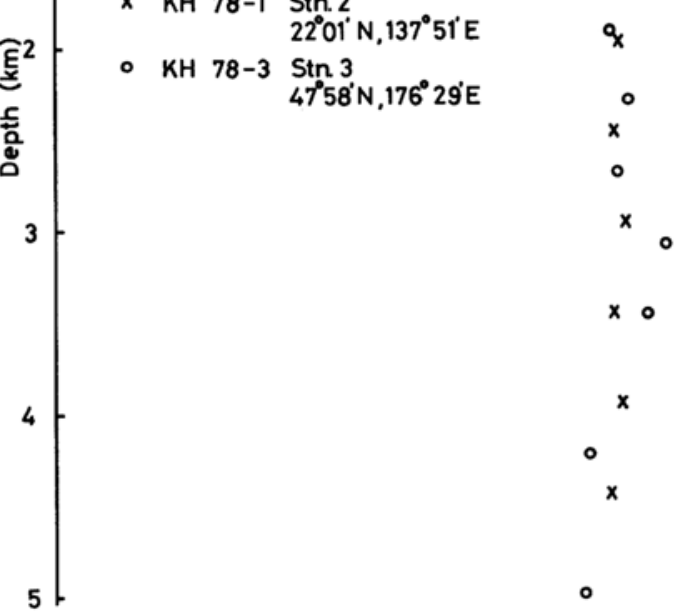

Fig. 5. Vertical distributions of $\mathrm{Ca}$ in the North Pacific, as examples, at the warm surface water station ( $\mathrm{KH}$ $78-1$, Stn 2) and the cold surface water station ( $\mathrm{KH}$ 78-3, Stn 3). The concentration of $\mathrm{Ca}$ is normalized to a salinity of $35.000 \%$.

elements in the model are given by TsunOGAI (1972a);

$$
\mathrm{S}=\mathrm{c}_{1}+\mathrm{c}_{2} \exp \left(-\frac{\mathrm{W}}{\mathrm{D}} \mathrm{z}\right)
$$

Table 1. Concentrations of Ca normalized to the salinity of $35.000 \%$ in the various water types*

\begin{tabular}{|c|c|c|c|c|c|c|c|c|}
\hline \multirow{2}{*}{$\begin{array}{c}\text { Depth } \\
\text { km } \\
0-0.2\end{array}$} & \multicolumn{2}{|c|}{$\begin{array}{c}\text { Western North } \\
\text { Pacific } \\
\text { (warm surface)** } \\
\mu \text { moles } / \mathrm{kg}\end{array}$} & \multicolumn{2}{|c|}{$\begin{array}{l}\text { Northern North } \\
\text { Pacific } \\
\text { (cold surface) } \\
\mu \text { moles } / \mathrm{kg}\end{array}$} & \multicolumn{2}{|c|}{$\begin{array}{c}\text { Eastern North } \\
\text { Pacific } \\
\mu \text { moles } / \mathrm{kg}\end{array}$} & \multicolumn{2}{|c|}{$\begin{array}{l}\text { Bering Sea } \\
\mu \text { moles } / \mathrm{kg}\end{array}$} \\
\hline & (32) & $10,170 \pm 5$ & (31) & $10,213 \pm 5$ & (12) & $10,201 \pm 7$ & (96) & $10,210 \pm 7$ \\
\hline $0.2-1$ & (39) & $10,217 \pm 25$ & (16) & $10,228 \pm 7$ & (6) & $10,229 \pm 10$ & (34) & $10,228 \pm 13$ \\
\hline $1-2$ & (52) & $10,248 \pm 14$ & (15) & $10,249 \pm 6$ & (9) & $10,253 \pm 6$ & (29) & $10,251 \pm 4$ \\
\hline $2-3$ & (49) & $10,256 \pm 9$ & (7) & $10,255 \pm 5$ & (5) & $10,246 \pm 7$ & (15) & $10,255 \pm 6$ \\
\hline $3-4$ & (40) & $10,252 \pm 8$ & (7) & $10,254 \pm 4$ & (4) & $10,253 \pm 5$ & (14) & $10,259 \pm 4$ \\
\hline$>4$ & (25) & $10,252 \pm 8$ & (3) & $10,250 \pm 4$ & (3) & $10,259 \pm 9$ & & \\
\hline
\end{tabular}

* One sigma value (S.D.) of the variation is attached to each mean value and numbers of samples are shown in parentheses.

** Stations shown in Fig. $2 a$. 


$$
R=c_{3}+c_{4} \exp \left(-\frac{W}{D} z\right)-\frac{J}{W} z
$$

where $c_{1}, c_{2}, c_{3}$, and $c_{4}$ are the integral constants determined by boundary conditions, $z$ is the depth, $\mathrm{D}$ and $\mathrm{W}$ are the vertical eddy diffusion coefficient and advection velocity, respectively. The ratio of W/D is determined by a conservative element such as salinity and potential temperature, which is known to be $1.1 \pm 0.3 \mathrm{~km}^{-1}$ in the North Pacific deep water (TsunOGaI, 1972a) and can be determined simply by the method of TsuNOGAI (1972b). The vertical advection velocity ( $W$, upwelling velocity) as well as the diffusion coefficient is also estimated to be 4.4 $\pm 1.2 \mathrm{~m} / \mathrm{yr}$ or $(1.5 \pm 0.4) \times 10^{-5} \mathrm{~cm} / \mathrm{sec}$ by TsuNOGAI (1972b). For simplicity in the calculation, the depth, $z=0$, is set at the upper boundary and $a$ is the thickness of the water

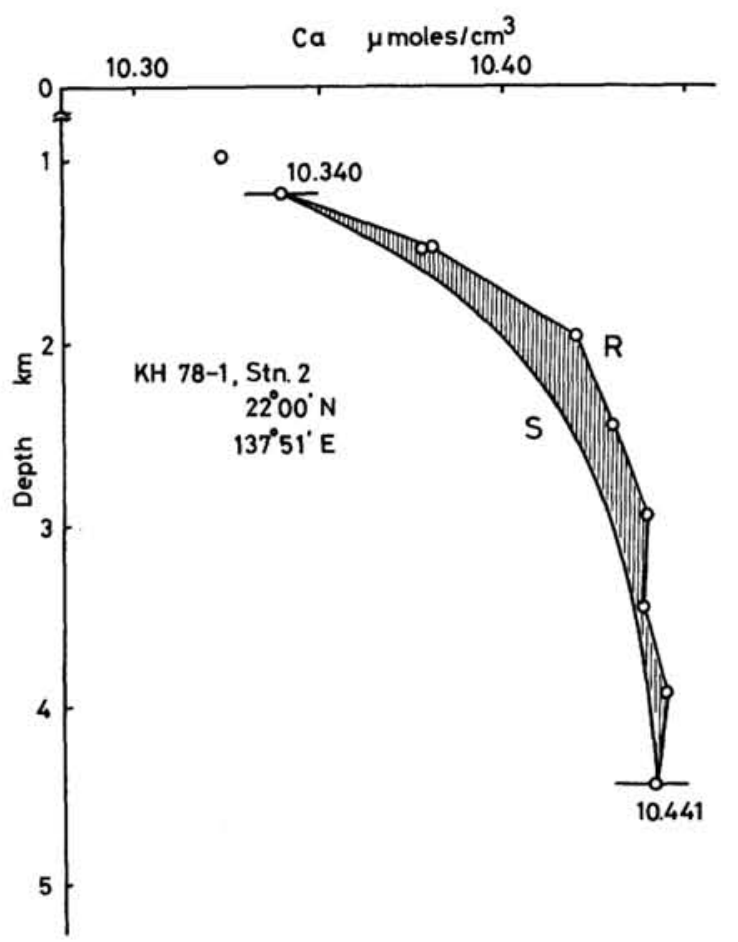

Fig. 6. An example of the graphical estimation of the dissolution rate of $\mathrm{Ca}\left(\mathrm{J}\right.$ in moles $\left./ \mathrm{cm}^{3} / \mathrm{yr}\right)$ with the onedimensional diffusion and advection model described in the text. $S$ and $R$ refer to conservative and nonconservative components, respectively. layer between the upper and lower boundaries. Since the curve of $\mathrm{S}$ is of the case without addition of dissolved $\mathrm{Ca}$, the hatched area (A) in Fig. 6 is caused by the dissolution of $\mathrm{Ca}$ in the water column and expressed by assuming that $\mathrm{J}$ is constant with depth as follows;

$$
\begin{aligned}
A & =\int_{0}^{a}(R-S) d z \\
& =\int_{0}^{a}\left\{\left(c_{3}-c_{1}\right)+\left(c_{4}-c_{2}\right) \exp \left(-\frac{W}{D} z\right)\right. \\
& =\frac{J}{W} \cdot a\left\{\frac{\left.\frac{J}{W} z\right\} d z}{1-\exp \left(-\frac{W}{D} a\right)}-\frac{D}{W}\right\}
\end{aligned}
$$

In the above equations, the integral constants are eliminated by the two boundary conditions that $\mathrm{R}$ is equal to $\mathrm{S}$ at both the two boundaries. From equation (4) we get the following relation at a mean condition in the deep Pacific described above and the thickness of deep water, a, of $4 \mathrm{~km}$;

$$
\mathrm{J}=9.6 \times 10^{-9} \mathrm{~A}
$$

where the units are $\mathrm{m} \mathrm{mole} / \mathrm{cm}^{3} / \mathrm{yr}$ and $\mathrm{m}$ mole/ $\mathrm{cm}^{2}$ for $\mathrm{J}$ and $\mathrm{A}$, respectively. The amounts of

\begin{tabular}{|c|c|}
\hline Station and location & $\stackrel{\mathrm{J}}{\mathrm{J}} 10^{-11} \mathrm{moles} / \mathrm{cm}^{3} / \mathrm{yr}$ \\
\hline $\mathrm{KH}-75-4, S \operatorname{tn} 33,47^{\circ} 55^{\prime} \mathrm{N}, 171^{\circ} 01^{\prime} \mathrm{E}$ & 4 \\
\hline $\mathrm{KH}-77-2, \operatorname{Stn} 9,33^{\circ} 01^{\prime} \mathrm{N}, 142^{\circ} 31^{\prime} \mathrm{E}$ & 12 \\
\hline $\mathrm{KH}-77-4, \operatorname{Stn} 50,29^{\circ} 58^{\prime} \mathrm{N}, 145^{\circ} 40^{\prime} \mathrm{E}$ & 6 \\
\hline $\mathrm{KH}-77-4, S \operatorname{tn} 133,30^{\circ} 59^{\prime} \mathrm{N}, 134^{\circ} 33^{\prime} \mathrm{E}$ & 8 \\
\hline $\mathrm{KH}-77-4, \operatorname{Stn} 153,30^{\circ} 08^{\prime} \mathrm{N}, 135^{\circ} 46^{\prime} \mathrm{E}$ & 5 \\
\hline $\mathrm{KH}-78-1$, Sth $1,26^{\circ} 11^{\prime} \mathrm{N}, 136^{\circ} 42^{\prime} \mathrm{E}$ & 5 \\
\hline $\mathrm{KH}-78-1, \operatorname{Stn} 2,22^{\circ} 01^{\prime} \mathrm{N}, 137^{\circ} 51^{\prime} \mathrm{E}$ & 5 \\
\hline $\mathrm{KH}-78-1, \operatorname{Stn} 4,12^{\circ} 55^{\prime} \mathrm{N}, 136^{\circ} 28^{\prime} \mathrm{E}$ & 5 \\
\hline $7,26^{\circ} 13^{\prime} \mathrm{N}, 129^{\circ} 37^{\prime} \mathrm{E}$ & 4 \\
\hline $\mathrm{KH}-78-1, \operatorname{Stn} 9,31^{\circ} 30^{\prime} \mathrm{N}, 136^{\circ} 59^{\prime} \mathrm{E}$ & 6 \\
\hline $\mathrm{KH}-78-1, \operatorname{Stn} 11,29^{\circ} 40^{\prime} \mathrm{N}, 146^{\circ} 15^{\prime} \mathrm{E}$ & 3 \\
\hline $\mathrm{KH}-78-3, \mathrm{Stn} 3,47^{\circ} 58^{\prime} \mathrm{N}, 176^{\circ} 29^{\prime} \mathrm{E}$ & 4 \\
\hline $\mathrm{KH}-78-3, \operatorname{Stn} 4,53^{\circ} 34^{\prime} \mathrm{N}, 177^{\circ} 12^{\prime} \mathrm{E}$ & 7 \\
\hline Mean & 5.7 \\
\hline
\end{tabular}
A have been determined graphically. The calculated results are listed in Table 2. Both the

Table 2. Dissolution rate of $\mathrm{Ca}$ in the deep water $(\mathrm{J})$ calculated with the one-dimensional diffusion and advection model 
highest and the lowest $\mathrm{J}$ values in the table have been obtained at stations located in the western boundary current area where the one-dimensional diffusion and advection model is difficult to be applied as found by TsuNOGAI et al., (1973b). A mean of the $\mathrm{J}$ value is $6 \times 10^{-11}$ moles $/ \mathrm{cm}^{3} / \mathrm{yr}$ and thus an amount of $\mathrm{Ca}$ dissolved in the water column of $4 \mathrm{~km}$ long is calculated to be $2.3 \times 10^{-5} \mathrm{moles} / \mathrm{cm}^{2} / \mathrm{yr}$ or 9 $\mathrm{gCa} / \mathrm{m}^{2} / \mathrm{yr}$, which shows a good agreement with the input rate of $\mathrm{Ca}$ to the deep water of $8 \mathrm{gCa} /$ $\mathrm{m}^{2} / \mathrm{yr}$ (Tsunogal, 1978). The latter value have been obtained by applying "settling model" of Tsunogai and Minagawa (1978) and the observed concentration ratio (1.007) of $\mathrm{Ca}$ in the deep to that in the surface. This calculation is also possible for alkalinity. Unfortunately we do not have the precise values of alkalinity at these deep stations in the North Pacific.

2) Relation between $\mathrm{Ca}$ and alkalinity in the surface water of the Bering Sea

The Bering Sea is famous for high biological productivity especially in summer time (e.g.
(TAGUCHI, 1972). Therefore great depression in the concentration of nuturients such as nitrate is observed in the surface water of the Bering Sea as shown in Fig. 7. It is very interesting to note that the vertical profiles of alkalinity shows a reflected image of those of nitrate or phosphate and we can make a straight line which is nearly constant with depth, when we plot the potential alkalinity, the sum of total alkalinity, nitrate and phosphate, versus depth (Fig. 7). The small increment of potential alkalinity with depth may be due to the formation and dissolution of $\mathrm{CaCO}_{3}$. Moreover, a slope of $\mathrm{Ca}$ plotted against the potential alkalinity agrees fairly well with the theoretical value of 0.5 for the waters including deeper waters, although a plot of $\mathrm{Ca}$ with total alkalinity measured shows a large deviation from the theoretical line (Fig. 8). This is evidence for BREWER et al. (1975)'s suggestion proposing that organic matter acts as a proton acceptor at formation or as a proton donor at its decomposition, in accordance with the relation given by REDFIELD et al. (1963). This clear relation between alkalinity and nu-

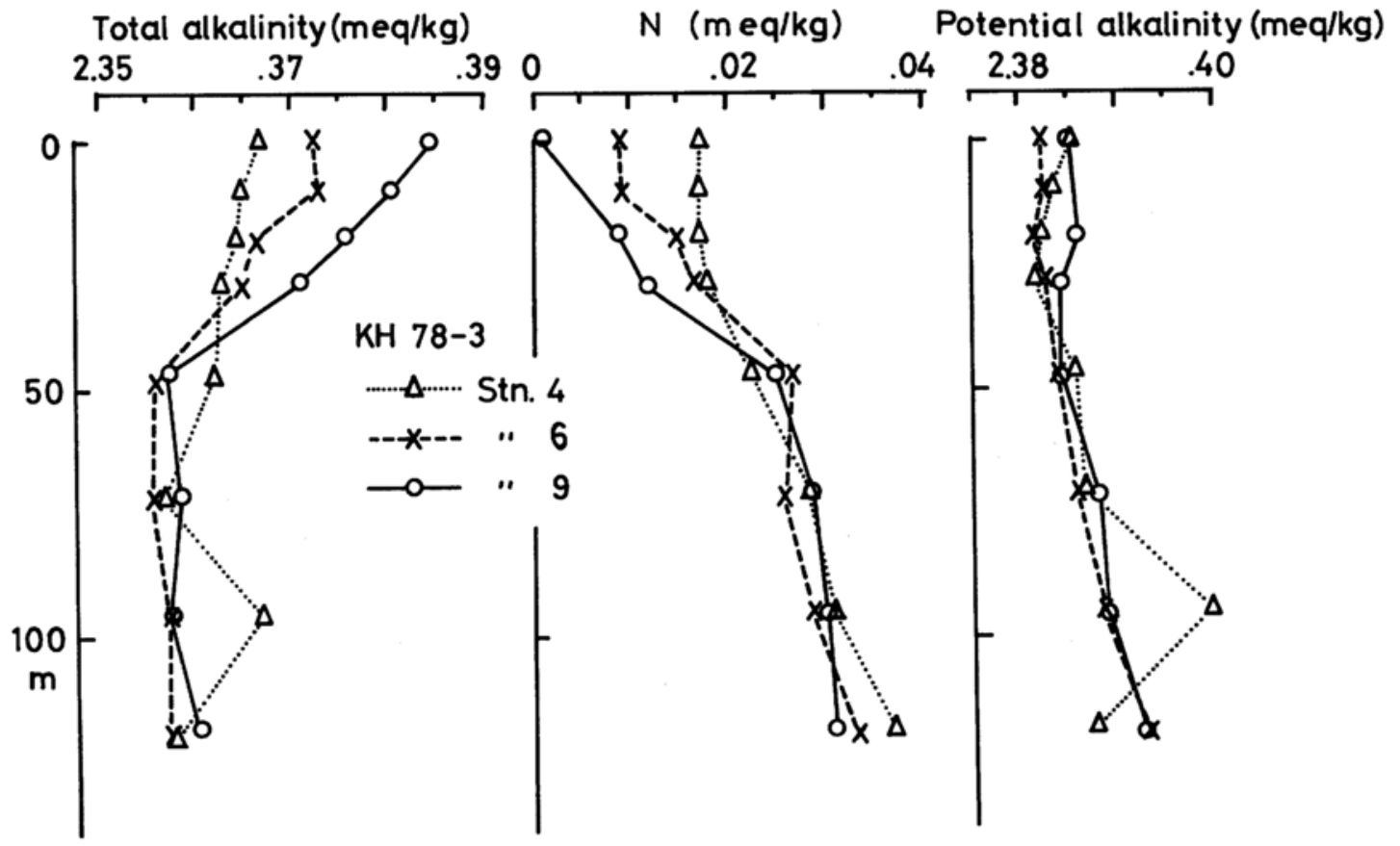

Fig. 7. Total alkalinity, potential alkalinity (the sum of total alkalinity, phosphate and nitrate) and nitrate in the surface water of the Bering Sea. These data are normalized to a salinity of $35.000 \%$. 
trients in the surface water of the Bering Sea may have resulted from the high biological activity and a single water mass which is confirmed by the preformed values of nutrients.

\section{3) Relation between $\mathrm{Ca}$ and alkalinity in the deep water}

In Fig. 9 is shown the relation between $\mathrm{Ca}$ and alkalinity for the data obtained at all the deep water stations and for surface samples during the cruise, $\mathrm{KH} \mathrm{78-3} \mathrm{in} \mathrm{the} \mathrm{northern}$ North Pacific and the Bering Sea. The deviation from the theoretical line is obvious for the relation between $\mathrm{Ca}$ and total alkalinity measured (Fig. 9a), but it is extremely lessened in the plot of Ca data against the potential alkalinity (Fig. 9b). The gradient of a regression line of $\mathrm{Ca}$ to potential alkalinity is calculated for waters above $1.5 \mathrm{~km}$ depth at each station and listed in Table 3. The gradients agree well with the theoretical value of 0.5 within the limit of uncertainties ( 0.53 as a mean or 0.54 as a median) and $\mathrm{Ca}$ is better correlated with potential alkalinity. This means that the difference in the preformed $\mathrm{Ca}$ between the surface and the subsurface waters is small in the North Pacific, if the above indication of the effect of organic matter on alkalinity is also true for the subsurface waters above $1.5 \mathrm{~km}$ depth. However, the relation between $\mathrm{Ca}$ and alkalinity is not

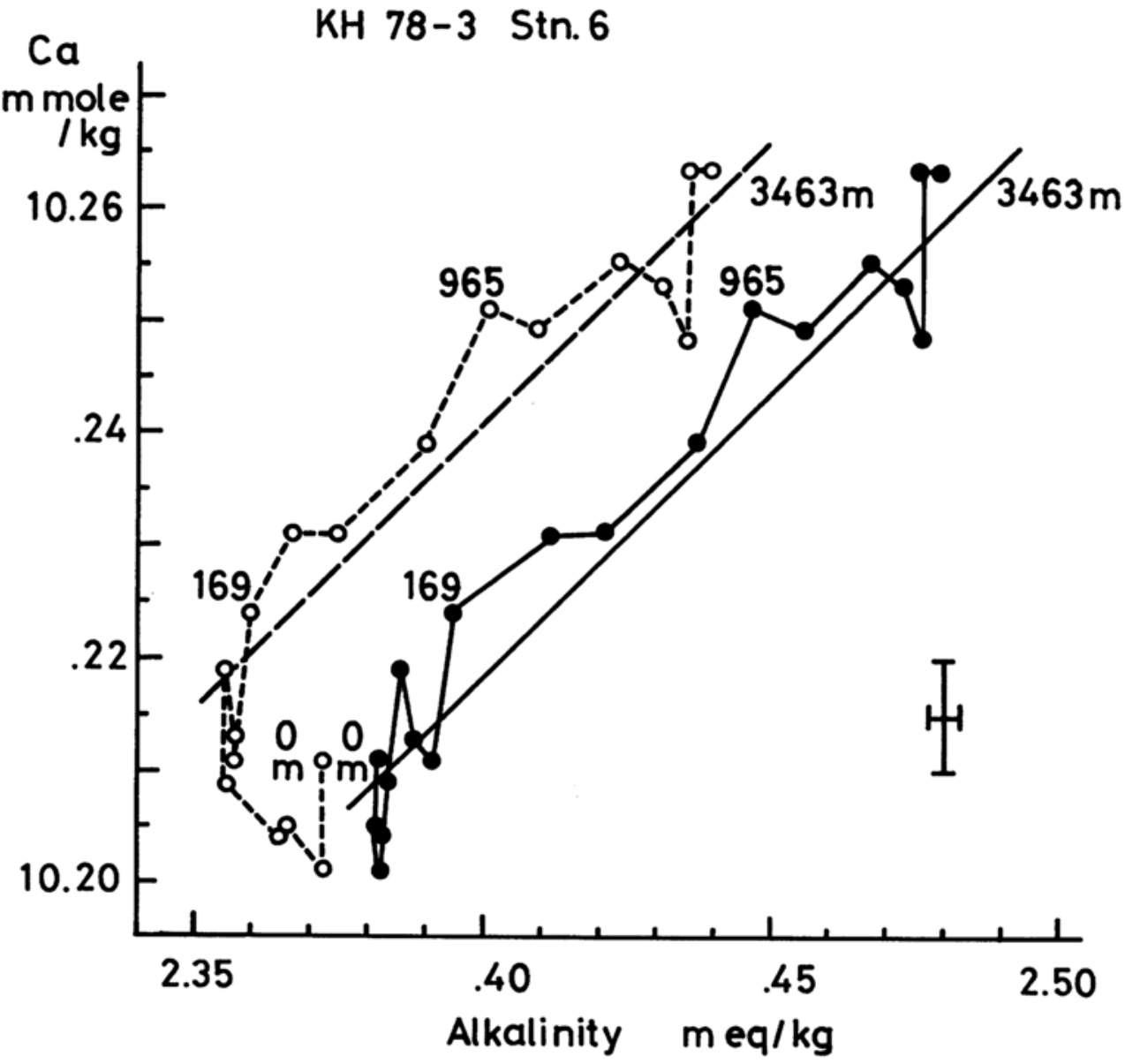

Fig. 8. Ca versus total alkalinity (open circles) or potential alkalinity (solid circles) in the Bering Sea (KH-78-3, Stn 6, as an example). The slope of straight lines is equal to the theoretical value of 0.5. Numerals refer to the depths of samples. These data are normalized to a salinity of $35.000 \%$. 
obvious for waters below $1.0 \mathrm{~km}$ depth as shown in Fig. 8. We have some other examples in that the potential alkalinity is constant or increases with depth whereas $\mathrm{Ca}$ decreases in the deep water. Since the deeper water is younger in the North Pacific deep water, this means that potential alkalintiy does not increase with time in proportion to the value theoretically expected from the nutrients increasing in the deep water. Unfortunately our data only in the northern North Pacific are insufficient to discuss this point in detail. More precise and extensive data on $\mathrm{Ca}$ and alkalinity as well as nutrients in the deep water along a meridional derection from the southern South Pacific to the northern North Pacific will provide useful information on this problem.

Acknowledgements-We wish to thank Prof. M. NISHIMURA and the staff of Laboratory of Analy tical Chemistry, Faculty of Fisheries, Hokkaido University for valuable discussions during this work. We are also grateful to Prof. A. HATTORI and the scientists, officers and crews aboard R. V. Hakuho-maru of University of Tokyo for assistance in obtaining the samples.

\section{REFERENCES}

BREWER, P. G. and GoldMAN, J. C. (1976) Alkalinity changes generated by phytoplankton growth. Limnol. Oceanogr. 21, 108-117.

BREWER, P. G., WONG, G. T. F., BACON, M. and

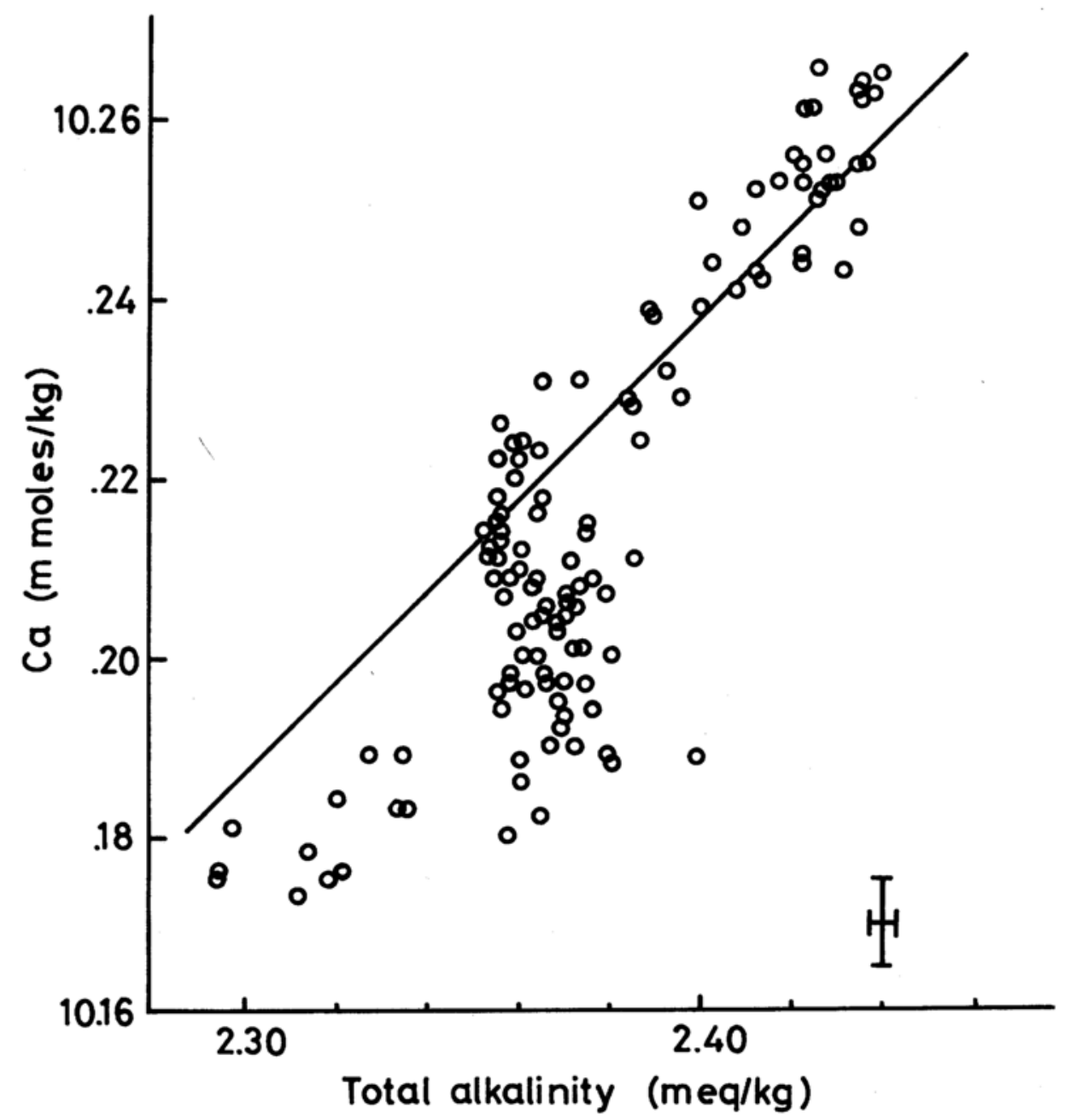

Fig. 9a 
SPENCER, D. (1975) An oceanic calcium problem? Earth Planet. Sci. Lett. 26, 81-87.

CHEN, C. T. (1978) Decomposition of calcium carbonate and organic carbon in the deep oceans. Science 201, 735-736.

CRAIG, H. (1969) Abyssal carbon and radiocarbon in the Pacific. J. Geophys. Res. 74, 5491-5506.

CULKIN, F. and CoX, R. A. (1966) Sodium, potassium, magnesium, calcium, and strontium in seawater. Deep-Sea Res. 13, 789-804.

DITTMAR, W. (1884) Report on researches into the composition of ocean-water collected by H.M.S. Challenger during the years 1873-76. The Voyage of H.M.S. Challenger ed. by J. MURRAY, (H.M. Stationary Office, London) Physics and Chemistry, Vol 1, 1-38.

HORIBE, Y., ENDO, K. and TSUbOTA, H. (1974)
Calcium in the South Pacific, and its correlation with carbonate alkalinity. Earth Planet. Sci. Lett. 23, 136-140.

REDField, A. C., Ketchum, B. H. and Richards, F. A. (1963) The influence of organisms on the composition of seawater. The Sea Vol. 2, M. N. HiLl ed. (Interscience, New York) 26-77.

SHILleR, O. A. M. and GIESKES, J. M. (1980) Processes affecting the oceanic distributions of dissolved calcium and alkalinity. J. Geophys. Res. 85, 27192727.

TAGUCHI, S. (1972) Mathematical analysis of primary production in the Bering Sea in summer. Biological oceanography of the Northern North Pacific Ocean, A. Y. TAKENOUTI ed. (Idemitsu Shoten, Tokyo) 253-262.

TSUNOGAI, S. (1972a) An estimate of the rate of

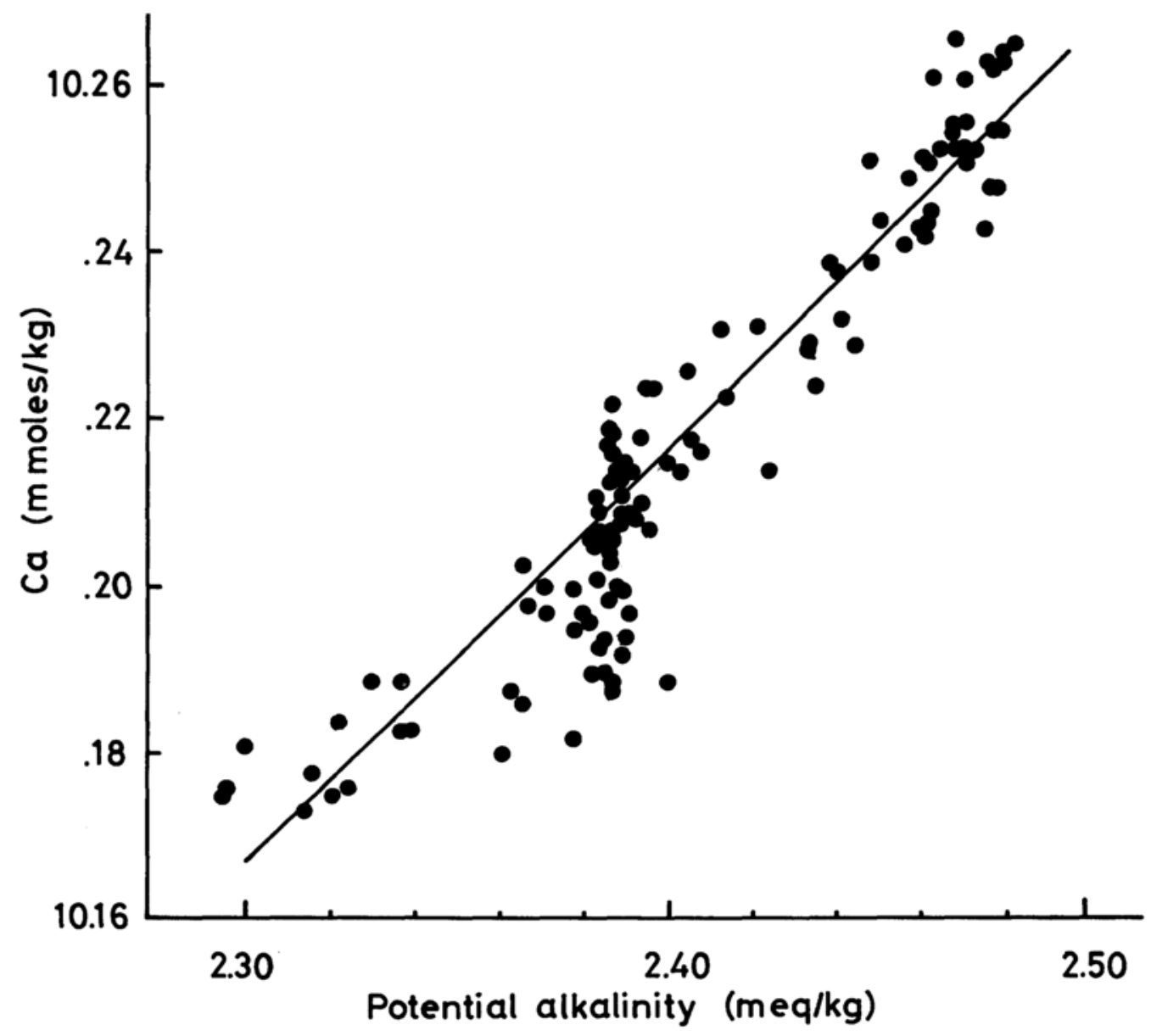

Fig. 9. Ca versus total alkalinity (Fig. 9a) or potential alkalinity (Fig. 9b) for waters collected at Stns. 3, 4, 6 , 8 and 34, and surface stations during the KH-78-3 cruise in the northern North Pacific and the Bering Sea. These data are normalized to a salinity of $35.000 \%$. 
Table 3. Relationship between Ca and total alkalinity or potential alkalinity for waters above $1,500 \mathrm{~m}$ depth in the northern North Pacific

\begin{tabular}{|c|c|c|c|c|c|c|}
\hline \multirow{2}{*}{\multicolumn{2}{|c|}{ Location }} & \multirow{2}{*}{$\begin{array}{c}\text { No. of } \\
\text { samples }\end{array}$} & \multicolumn{2}{|c|}{ Ca: Total alkalinity } & \multicolumn{2}{|c|}{ Ca: Potential alkalinity } \\
\hline & & & Gradient & $\begin{array}{l}\text { Correlation } \\
\text { coefficient }\end{array}$ & Gradient & $\begin{array}{c}\text { Correlation } \\
\text { coefficient }\end{array}$ \\
\hline \multicolumn{7}{|l|}{ North Pacific } \\
\hline \multicolumn{7}{|c|}{ KH-75-4, Stn } \\
\hline $4\left(49^{\circ} 32^{\prime} \mathrm{N}\right.$ & $\left.158^{\circ} 02^{\prime} \mathrm{E}\right)$ & 9 & 0.57 & 0.76 & 0.53 & 0.94 \\
\hline $6\left(54^{\circ} 31^{\prime} \mathrm{N}\right.$ & $\left.164^{\circ} 26^{\prime} \mathrm{E}\right)$ & 9 & 0.66 & 0.89 & 0.51 & 0.96 \\
\hline $26\left(49^{\circ} 59^{\prime} \mathrm{N}\right.$ & $\left.155^{\circ} 00^{\prime} W\right)$ & 11 & 0.56 & 0.88 & 0.46 & 0.93 \\
\hline $30\left(49^{\circ} 58^{\prime} \mathrm{N}\right.$ & $\left.144^{\circ} 28^{\prime} W\right)$ & 14 & 0.75 & 0.92 & 0.65 & 0.96 \\
\hline $33\left(47^{\circ} 55^{\prime} \mathrm{N}\right.$ & $\left.171^{\circ} 01^{\prime} \mathrm{E}\right)$ & 12 & 0.67 & 0.84 & 0.55 & 0.94 \\
\hline $35\left(46^{\circ} 57^{\prime} \mathrm{N}\right.$ & $\left.167^{\circ} 00^{\prime} \mathrm{E}\right)$ & 9 & 0.67 & 0.91 & 0.42 & 0.96 \\
\hline \multicolumn{7}{|l|}{ KH-78-3, Stn } \\
\hline $3\left(47^{\circ} 57^{\prime} \mathrm{N}\right.$ & $\left.176^{\circ} 26 \mathrm{E}\right)$ & 14 & 0.42 & 0.80 & 0.33 & 0.84 \\
\hline \multicolumn{7}{|l|}{ Bering Sea } \\
\hline \multicolumn{7}{|c|}{ KH-75-4, Stn } \\
\hline $7\left(56^{\circ} 58^{\prime} \mathrm{N}\right.$ & $\left.167^{\circ} 08^{\prime} \mathrm{E}\right)$ & 5 & 1.29 & 0.88 & 0.55 & 0.97 \\
\hline $8\left(57^{\circ} 00^{\prime} \mathrm{N}\right.$, & $\left.171^{\circ} 00^{\prime} \mathrm{E}\right)$ & 11 & 0.54 & 0.82 & 0.35 & 0.80 \\
\hline $9\left(57^{\circ} 00^{\prime} \mathrm{N}\right.$ & $\left.174^{\circ} 57^{\prime} \mathrm{E}\right)$ & 10 & 0.73 & 0.89 & 0.55 & 0.92 \\
\hline $10\left(57^{\circ} 01^{\prime} \mathrm{N}\right.$ & $\left.179^{\circ} 01^{\prime} \mathrm{E}\right)$ & 9 & 1.32 & 0.92 & 0.68 & 0.82 \\
\hline $11\left(57^{\circ} 03^{\prime} \mathrm{N}\right.$ & $\left.176^{\circ} 57^{\prime} W\right)$ & 9 & 0.70 & 0.70 & 0.63 & 0.90 \\
\hline $20\left(55^{\circ} 00^{\prime} \mathrm{N}\right.$ & $\left.168^{\circ} 01^{\prime} W\right)$ & 10 & 0.77 & 0.66 & 0.45 & 0.82 \\
\hline \multicolumn{7}{|c|}{$\mathrm{KH}-78-3$, Stn } \\
\hline $4\left(53^{\circ} 34^{\prime} \mathrm{N}\right.$ & $\left.177^{\circ} 09^{\prime} \mathrm{E}\right)$ & 13 & 0.70 & 0.84 & 0.51 & 0.93 \\
\hline $6\left(56^{\circ} 59^{\prime} \mathrm{N}\right.$, & $\left.177^{\circ} 01^{\prime} W\right)$ & 14 & 0.76 & 0.78 & 0.60 & 0.96 \\
\hline $8\left(58^{\circ} 00^{\prime} \mathrm{N}\right.$, & $\left.175^{\circ} 06^{\prime} w\right)$ & 9 & 0.70 & 0.76 & 0.61 & 0.92 \\
\hline $9\left(58^{\circ} 15^{\prime} \mathrm{N}\right.$ & $\left.174^{\circ} 31^{\prime} W\right)$ & 11 & 0.51 & 0.54 & 0.56 & 0.92 \\
\hline $34\left(56^{\circ} 08^{\prime} \mathrm{N}\right.$ & $\left.173^{\circ} 03^{\prime} w\right)$ & 13 & 0.67 & 0.85 & 0.53 & 0.96 \\
\hline \multicolumn{7}{|c|}{$\mathrm{KH}-78-3$} \\
\hline All including su & rface samples & 126 & 0.74 & 0.78 & 0.56 & 0.82 \\
\hline
\end{tabular}

decomposition of organic matter in the deep water of the Pacific Ocean. Biological oceanography of the Northern North Pacific Ocean, A. Y. TAKENOUTI, ed. (Idemitsu Shoten, Tokyo) 517-533.

TSUNOGAI, S. (1972b) An estimate of the vertical diffusivity of the deep water. J. Oceanogr. Soc. Japan 28, 145-152.

TSUNOGAI, S. (1978) Application of settling model to the vertical transport of soluble elements in the ocean. Geochem. J. 12, 81-88.

TSUNOGAI, S. (1980) Quantitative analysis of biological activity on the deep sea bottom. La mer (Bull. Soc. franco-japonaise d'oceanogr.) 18, 216226.

TsunOGaI, S. and Minagawa, M. (1978) Settling model for the removal of insoluble chemical elements in seawater. Geochem. J. 12, 47-56.
TSUNOGAI, S., NiSHIMURA, M. and NAKAYA, S. (1968) Complexometric titration of calcium in the presence of larger amount of magnesium. Talanta 15, 385390.

TSUnOGaI, S., Yamahata, H., Kudo, S. and Saito, 0. (1973a) Calcium in the Pacific Ocean. Deep-Sea Res. 20, 717-726.

TSUNOGAI, S., MATSUMOTO, E., KIDO, K., NoZAKI, Y. and HATTORI, A. (1973b) Two discontinuities in the deep water of the western North Pacific Ocean. Deep-Sea Res. 20, 527-536.

TSUNOGAI, S., WATANABE, Y. and YoKoYama, A. (1978) A precise method for the routine analysis of alkalinity. Abstract of paper presented at Annual Meeting of the Geochemical Society of Japan, Hakodate, Oct. 1978, p 1. 